\title{
Differential Object Marking and Language Contact: An Introduction to this Special Issue
}

\author{
Alexandru Mardale \\ Assistant Professor, Romanian Language and Linguistics, Institut National \\ des Langues et Civilisations Orientales (INaLCO), Paris, France \\ Researcher, Laboratoire Structure et Dynamique des Langues (SeDyL) \\ UMR 8202, CNRS, France \\ alexandru.mardale@inalco.fr
}

\begin{abstract}
Petros Karatsareas
Lecturer in English Language and Linguistics, School of Humanities, University of Westminster, London, United Kingdom

P.Karatsareas@westminster.ac.uk
\end{abstract}

This special issue includes a selection of papers that were presented at the international workshop themed Differential Object Marking and Language Contact that was organised by Anton Antonov (INaLCO, CRLAO) and Alexandru Mardale (INaLCO, SeDyL) in Paris on 5 and 6 December 2014 as part of the Unity and Diversity in Differential Object Marking research project under the sponsorship of the Fédération Typologie et Universaux Linguistiques of the CNRS. The project sets out to propose a typology of differential object marking (henceforth Dом) by bringing together specialists working on the phenomenon from different angles and on different languages, especially languages that have been less used by typologists to date, with the aim of advancing our understanding of this widespread linguistic phenomenon. One key objective in this connection is to examine the role language contact plays in determining the properties of Dом in particular ром languages, in triggering the emergence of Dом in previously ром-less languages, and in bringing about the loss of Фом in previously ром languages. This issue addresses this objective.

Traditionally, DOM has been understood as the phenomenon whereby only a subset of the direct objects in a language are overtly marked as such by using an affix, an adposition or some other means, while the remaining direct objects bear no overt marking of their syntactic function. Whether a given direct object will be overtly marked or not is defined on the basis of referential— that 
is, semantic or pragmatic - properties of the referent of the NP occupying the object position. In Russian, for example, masculine singular nouns in direct object NPs are overtly marked with the genitive/accusative suffix - $a$ only if they are animate (1a); inanimate nouns appear in a form identical to that of the nominative, which is unmarked for case ( $1 \mathrm{~b})$.

(1) Russian (Comrie, 1989: 132)
a. Yuri videl
PN see.PST.3SG boy(M)-SG.ACC
'Yuri saw the boy/hippopotamus.'
b. Yuri videl stol- $\varnothing$
PN see.PST.3SG table(M)- $\varnothing$
'Yuri saw the table.'

/ begemot-a
hippopotamus(M)-SG.ACC

More recently, however, an increasing number of scholars have begun studying DOM systems that do not show an alternation between an overt and zero marker, as in Russian, but between two different overt markers. In these cases, therefore, all direct objects in a language are overtly marked. One subset of objects, however, bears one type of overt marking, while the other subset bears a different overt marker, again depending on the referential properties of the direct object NP. In Ancient Greek, for example, direct objects that receive an indefinite or non-specific reading are marked with the genitive case (2a), whereas definite and specific direct objects are marked with the accusative case $(2 b)$.

(2) Ancient Greek (Riaño Rufilanchas, 2014: 529)
a. $t \hat{\bar{e}}-s$
$g \hat{\bar{e}}-s$
tem-eîn
DEF.F-SG.GEN land(F)-SG.GEN
ravage.AOR-INF.ACT
'to ravage some of the land'
b. $t \grave{\bar{e}}-n$
$g \grave{e}-n$
$\operatorname{land}(\mathrm{F})$-SG.ACC
tem-eîn
DEF.F-SG.ACC
ravage.AOR-INF.ACT
'to ravage the land'

DOM is by now a well-known and well-described phenomenon (Comrie, 1979; Bossong, 1985, 1998; Croft, 1988; Lazard, 1994, 2001; Iemmolo, 2010, 2011, 2013; Dalrymple and Nikolaeva, 2011, among many others). Research over the past thirty years has allowed us to grasp the key parameters at work in case-marking alternations such as the ones exemplified in (1) and (2) above (Hopper and Thompson, 1980; Laca, 2002, 2006; Aissen, 2003; Leonetti, 2004, 2008; Næss, 2004; von Heusinger and Kaiser, 2007; de Swart and de Hoop, 2007; Seržant 
and Witzlack-Makarevich, 2018). This bulk of research has also contributed to more fine-grained descriptions of the phenomenon in a number of languages, mainly from a synchronic but also, for some languages, from a diachronic point of view, as well. In contrast, the role of language contact in the emergence, development and loss of a Dом system has been the object of less attention. Contact-induced innovations in Dом systems are indeed attested and have been described for individual language pairs in the existing literature, but there have not been many attempts to view these collectively or to examine the implications they have for the study of D OM from a larger, typological point of view.

In a language contact setting where at least one of the two languages involved displays DoM, there are at least two scenarios to be considered:

1. Symmetrical scenario: both languages have their own DOM systems conditioned by factors which may or may not differ. At some point in their history, the two languages come in contact with each other, and their DOM systems begin to interact. There are two further sub-types in this case:

a. The two Dом languages influence each other reciprocally and both DOM systems undergo change.

b. Only one of the two Dом languages influences the other. The Dом system of the influencer language remains diachronically unchanged, whereas the Dом system of the influenced language undergoes change.

2. Asymmetrical scenario: one of the two languages has a Dом system, while the other one does not. At some point in their history, the two languages come in contact with each other, and their direct object marking systems begin to interact. There are two further sub-types in this case:

a. The ром language influences the ром less language. As a result, the Dом less language begins to exhibit DOM.

b. The Dом less language influences the Dом language. As a result, either the DOM system of the DOM languages is weakened or the DOM language loses DOM altogether.

An asymmetrical scenario of the first sub-type whereby a DOM less language acquires Dом could result in either one of the two types of replication identified by Matras (2009) and Sakel (2007; see also Matras and Sakel, 2007): pattern replication and matter replication. In pattern replication, the ром less language would reorganise its direct object marking system in the model of the ром language without borrowing the actual ром marker. Instead, it would redistribute its existing direct object markers using (a version of) the referential properties that determine the distribution of the Dом markers in the model language. In matter replication, the Dom less language would additionally borrow the ром marker from the ром language. Our case studies, 
however, suggest that, while both these options are possible in theory, pattern replication seems to be more widespread when it comes to DOM. Matter or pattern-plus-matter replication, in contrast, seems to be rare.

Against this backdrop, the contributions in this issue set out to address the following research questions:

1. Can we be sure as to the exact scenario involved, that is, symmetrical versus asymmetrical?

2. In a seemingly symmetrical scenario, is it possible that the two languages acquired their respective Dом systems independently from each other?

3. What role does further contact between two Dом languages play in the development (and/or possible demise) of their respective DoM systems?

4. To what extent can contact be construed as the only, or at least, the key factor in the emergence of a DOM system in language contact scenario between a DOM less and a DОм language?

In what follows, we briefly present one case study of the outcomes of language contact between a DOM and a DOM less language to illustrate the type of approach that the contributions of this special issue adopt. We then go on to present the articles included in the special issue, summarise their main findings and highlight their contribution towards providing answers to the research questions listed above.

Romanian and Italian in Contact: DOM with care, the pe/la Alternation and Double Object Constructions

A very interesting case study is presented by the changes observed in the Romanian varieties spoken by first-generation Romanian immigrants in Italy who are in contact with Standard Italian. Unlike other Romance languages such as Spanish, Standard Italian has a very limited Dом system in that it does not typically use a specific grammatical tool to mark direct objects. Compare the Italian examples in (3) with the Spanish ones in (4). In Spanish, $a$ marks direct object NPs whose referents are human and take a specific reading. However, when first and second pronouns and, less commonly, third person pronouns and proper names are topicalised and left-dislocated, they may be marked by the preposition $a$ (Benincà, 1986; Berretta, 1989; Iemmolo, 2011). See (5).

(3) a. Standard Italian

$\begin{array}{llll}\text { Ho } & \text { visto } & \varnothing & \text { Paolo. } \\ \text { AUX.PRS.1SG } & \text { see.PTCP } & & \text { PN } \\ \text { 'I saw Paolo.' } & & & \end{array}$




\begin{tabular}{|c|c|c|c|}
\hline${ }^{*} \mathrm{Ho}$ & visto & $a$ & Paolc \\
\hline AUX.PRS.1SG & see.PTCP & DOM & $\mathrm{PN}$ \\
\hline
\end{tabular}

(4) a. Standard Spanish

$\begin{array}{lll}\text { Vi } & a & \text { Pablo. } \\ \text { see.PST.1SG } & \text { DOM } & \text { PN } \\ \text { 'I saw Pablo.' } & & \end{array}$

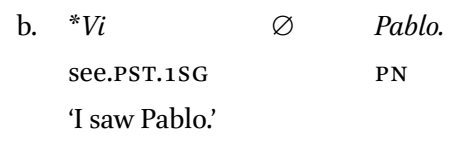

(5) Standard Italian (Iemmolo, 2010: 249).

$\begin{array}{llllll}A & t e, & \text { non } & t i & \text { sopporto } & \text { più. } \\ \text { DOM } & \text { 2SG.ACC } & \text { NEG } & \text { CL.ACC.2SG } & \text { tolerate.PRS.1SG } & \text { more }\end{array}$

'I cannot stand you any longer.'

Standard Literary Romanian (henceforth SLR) has a full-fledged DOM system (Dobrovie-Sorin, 1994; Cornilescu, 2000; Mardale, 2009; Chiriacescu and von Heusinger, 2010; Pană Dindelegan, 2013; Hill and Mardale, 2019). The preposition $p e$ is used to mark direct objects whose referents are (human) animate and (semantically/pragmatically) specific. More precisely, $p e$ appears obligatorily with (strong) pronouns irrespective of the (animate or inanimate) nature of their referents (6a), with the exception of ceva 'something' or nimic 'nothing'. Pe also appears with the relative care when it functions as a direct object by virtue of it being a pronoun and irrespective of the nature of its referent (6b).

(6) Standard Literary Romanian

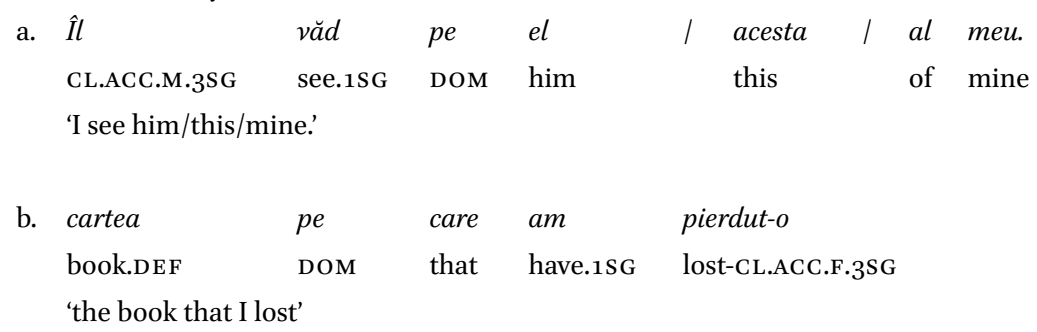

DOM is also obligatory with direct objects that are realised as (personal/ animate) proper nouns and functional nouns, that is nouns that have unique 
referents such as 'God' or refer to family members such mother, son, brother or cousin. It is also obligatory with definite specific direct objects that have a human referent (7):

(7) Standard Literary Romanian

$\begin{array}{llllllll}\hat{I l} & \text { văd } & \text { pe } & \text { Grivei } & \text { / tata } & \text { primar } \\ \text { CL.ACC.M.3SG } & \text { see.1SG } & \text { DOM } & \text { PN.M.SG } & \text { father } & \text { mayor }\end{array}$

'I see Grivey/(my) father/the Mayor.'

DOM is optional with direct objects realised as indefinite NPs whose referents are human and specific. Compare (8a) where ром is absent and the direct object is interpreted as non-specific with $(8 \mathrm{~b})$ where DOM may appear and the direct object is therefore interpreted as specific:

(8) Standard Literary Romanian
a. Văd un copil.
see.1SG INDF.M.SG child
'I see a child (that I do not know).'
b. (îll) văd pe un copil.
CL.ACC.M.3SG see.1SG DOM INDF.M.SG child
'I see a child (that I know).'

DoM is excluded with direct objects realised as nominal expressions whose referents are non-specific (typically bare nouns) or inanimate as in (9):

(9) Standard Literary Romanian
a. Văd copii.
see.1SG children
'I see children.'
b. Văd casa $\quad$ / o casă.
see.1SG house.DEF INDF.F.SG house
'I see the house/a house.'

DOM in SLR is related to another syntactic phenomenon, clitic doubling in that clitic-doubling is found only in contexts where DOM is also found. Clitic doubling is obligatory in the cases where DOM is obligatory (i.e. with pronouns, proper names, strong definite specific NPs) as in (6) and (7a) above. It is optional when the specificity of the DO is weaker, i.e., with indefinite NPs as in 
(8b). In the latter case, if clitic doubling appears, specificity is stronger than when clitic doubling does not appear (Hill and Mardale, 2017, 2019).

In the Romanian of immigrants in Italy documented by Cohal (2014), pe is absent in some contexts in which it would be found in SLR but in which Italian uses no marking. We focus here on two such contexts: the marking of the relative care when it functions as a direct object, and the alternation observed in some verbs in marking their direct objects with la or with the DOM marker $p e$.

Starting with care, in the SLR example in (10a), the use of $p e$ is obligatory by virtue of care being a pronoun. Observe also that clitic doubling is also obligatory here as it correlates with the obligatory use of Dом. In Italian Romanian, however, the relative clause appears without the DoM marker (1ob), which Cohal attributes to the fact that the equivalent construction in Standard Italian does not involve a direct object marker; see (11). It has to be noted, however, that the absence of $p e$ with care (and, by extension, the lack of clitic doubling) is also found in colloquial varieties of Romanian spoken in Romania (Avram, 1997: 367-370, Nedelcu, 2012: 127-129).

(10) a. Standard Literary Romanian (Cohal, 2014: 174)

$\begin{array}{lllllll}\text { fata } & \text { pe } & \text { care } & \text { el } & a & \text { incercat } & \text { s-o } \\ \text { girl(F).DEF } & \text { DOM } & \text { REL } & \text { 3.M.SG } & \text { AUX.PRS.3SG } & \text { try.PTCP } & \text { SUBJ-CL.3.F.SG.ACC } \\ \text { salveze } & & & & & & \\ \text { save.SUBJ.3 } & & & & \\ \text { 'the girl he tried to save' } & & & \end{array}$

b. Italian Romanian

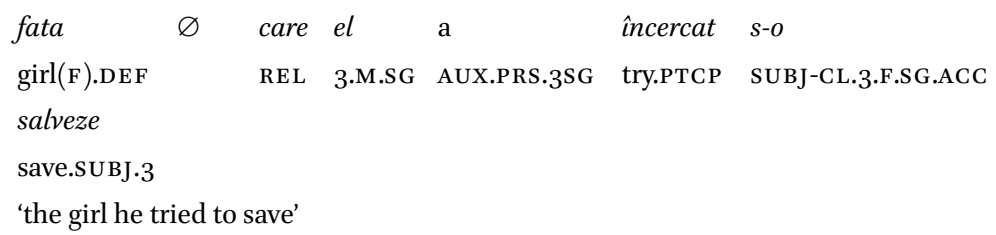

(11) Standard Italian

$\begin{array}{lllllllll}\text { la } & \text { ragazza } & \varnothing & \text { che } & \text { lui } & \text { ha } & \text { provato } & a & \text { salvare } \\ \text { DEF.F.SG } & \text { girl(F).sg } & \text { REL } & \text { 3.M.SG } & \text { AUX.PRS.3.SG } & \text { try.PTCP } & \text { ALL } & \text { save.INF } \\ \text { 'the girl he tried to save' } & & & & & & \end{array}$

Turning now to the pe/la alternation, SLR exhibits an alternation between the Dом marker $p e$ and the locative marker la with some verbs as in (12a). The alternation is not completely free but encodes a fine semantic difference. $\mathrm{Pe}$ marked constructions are more transitive in the sense that the referent of 
the direct object is interpreted as showing a higher degree of affectedness. In contrast, in la-marked constructions, the direct object is interpreted as being less affected and is read more like an (abstract locative) adjunct. Italian Romanian, on the other hand, displays only la (12b), replicating the use of the allative/locative $a$ in Standard Italian (13). Again, Cohal attributes this to contact with Standard Italian.

(12) a. Standard Literary Romanian (Cohal, 2014: 175)

când mai mergi strigă și pe/la noi

when again go.PRS.2SG call.IMP.2SG and DOM/LOC 1PL

'Give us a shout when you go there again.'

b. Italian Romanian

$\begin{array}{lllllll}\text { când } \quad \text { mai } & \text { mergi } & \text { strigă } & \text { și } & \text { la } & \text { noi } \\ \text { when } & \text { again } & \text { go.PRS.2SG } & \text { call.IMP.2SG } & \text { and } & \text { LOC } & 1 \mathrm{PL} \\ \text { 'Give us a shout when you go there again.' } & & & \end{array}$

(13) Standard Italian

$\begin{array}{lllllll}\text { quando } & \text { vai } & \text { dinuovo } & \text { strilla } & \text { anche } & a & \text { noi } \\ \text { when } & \text { go.PRS.2SG } & \text { again } & \text { call.IMP.2SG } & \text { and } & \text { ALL } & \text { 1PL }\end{array}$

'Give us a shout when you go there again.'

In other cases, $l a$ appears in contexts in which SLR only allows for the use of $p e$ as in (14b), again due to the semantic similarity between $l a$ and Standard Italian $a$ and the use of the latter in the corresponding structures as in (15). However, if the construction in (14) is analysed as a double-object construction, then it has to be noted that, in SLR, a dative NP 'to someone' can be expressed either as pe cineva 'to someone' (with DOM) or as a morphological dative form cuiva, which is often replaced by la in colloquial style.

(14) a. Italian Romanian (Cohal, 2014: 175)

$\begin{array}{llllllll}e u & \text { vroiam } & \text { să } & \text { intreb } & \text { niște } & \text { prețuri } & \text { la } & e i \\ \text { 1SG } & \text { want.IMPRF.1.SG } & \text { SUBJ } & \text { ask.PRS.1SG } & \text { some } & \text { price.PL } & \text { LOC } & \text { 3PL }\end{array}$

'I wanted to ask them about some prices.'

b. Standard Literary Romanian

$\begin{array}{lllllll}\text { vroiam } & \text { să-i } & \text { intreb } & \text { niște } & \text { prețuri } & \text { pe } & \text { ei } \\ \text { want.IMPRF.1.SG } & \text { SUBJ-3PL.ACC } & \text { ask.PRS.1SG } & \text { some } & \text { price.PL } & \text { DOM } & \text { 3PL } \\ \text { 'I wanted to ask them about some prices.' } & & & & \end{array}$


(15) Standard Italian

$\begin{array}{lllll}\text { volevo chiedere dei prezzi } & \text { a loro }\end{array}$

want.IMPFV.1SG ask.INF PART.M.PL price(M).PL ALL 3PL

'I wanted to ask them about some prices.'

In Italian Romanian, we are therefore able to observe the nascent effects of the contact between a DOM language and an (almost) DOM less one in what qualifies as a case of the second sub-type of the asymmetrical scenario outlined above. The typological and lexical similarities between the two Romance languages and the lack of normative pressure in the diasporic context in which Romanian migrants use their heritage language can only be considered as contributing factors to the weakening of the Romanian Doм system through the reduced use of $p e$. It has to be noted, however, that, in all of the cases that we briefly reviewed, the tendencies to drop $p e$ already exist in colloquial varieties of Romanian spoken in Romania. It can therefore not be a coincidence that language contact in Italian Romanian affects exactly these vulnerable aspects of the language's DOM system. What language contact seems to be doing in this case is push forward dynamics that were already in place in the system prior to the onset of the contact.

\section{The Contributions}

In her contribution, Daniela Boeddu deals with ром in the Arborense variety of Sardinian dialect, focusing on the interpretation of the variability of DOM in contemporary Sardinian as a consequence of contact with Standard Italian. She compares the distribution of Arborense DOM as it is observed in an oral corpus with that of other Sardinian varieties as well as with the results of the study of a diachronic corpus. She finds that the limits in the distribution of the DOM marker in the Arborense data differ from the descriptions of DOM in Campidanian, Logudorian and Nuorese: for personal names, Arborense shows a low degree of variation, whereas this type of NP is always considered part of the obligatory Dом domain in other varieties of Sardinian; for animate common nouns, contemporary Arborense DOM as well as DOM in other Sardinian varieties shows a certain degree of vitality but also extensive flexibility. Based on the results of her investigation, Boeddu revisits the proposal put forward by Putzu (2005) and Blasco Ferrer and Ingrassia (2010), who suggest that the variability of ром in Modern Sardinian reflects the influence of Standard Italian. First, diachronic data suggest that variation in contemporary Sardinian DOM is 
due to language-internal factors and cannot be attributed to contact with Standard Italian. Second, it is important that, in analysing the language contact situation, both Standard and Regional Italian must be taken into account. As already shown above, whereas the former has a very limited ром system, the latter shows a robust DOM system akin to that of the Sardinian dialects. Finally, Boeddu argues that Standard Italian could influence Sardinian by weakening its Dом system, whereas the influence of the Regional Italian could result in its diachronic maintenance.

Eleni Bužarovska re-examines the existing contact hypothesis regarding the origin of Dом in peripheral Macedonian dialects. From a Balkan Sprachbund perspective, these dialects represent smaller convergence areas characterized by intense multilinguism. The use of the analytic dative marker $n a$ with definite animate direct objects has been traditionally ascribed to contact with the neighbouring dialects of Aromanian and Greek. Bužarovska argues that contact triggered the emergence of Dом in these Balkan Slavic dialects in an indirect way, targeting the noun inflection and case marking system that they inherited from their South Slavic ancestor. Structural changes involving extensive grammatical simplification obscured case relations and increased the necessity to disambiguate the roles of clause participants. The resultant contactinduced structural ambiguity was resolved by replicating the analytic dative pattern to mark human objects. The author provides diachronic evidence that $n a$-marking originally functioned as a distinguishing strategy but evolved into a discourse prominence strategy that extended to inanimate objects. The speakers of these peripheral dialects use Dом when they want to ascribe prominent discourse status to the second participant of the narrated event.

Avelino Corral Esteban investigates DOM in Vaqueiru Asturian, a Western Iberian Romance variety spoken in western Asturias (northwestern Spain), which has been able to retain most of its distinctive characteristics due to almost complete cultural isolation. Corral Esteban examines the behaviour of direct objects with respect to a number of semantic and discourse-pragmatic parameters in order to establish what triggers the distribution of Dом in this Asturian variety. By including not only Western Asturian examples but also the equivalent structures in Standard Spanish and Central Asturian, which is considered the normative variety of the language, he identifies the differences between these three varieties in terms of object marking. His findings reveal that the use of Dом in Vaqueiru Asturian does not appear to be determined by criteria such as animacy, definiteness, specificity, referentiality or the degree of affectedness of the object. Rather, it only appears to be obligatory with topicalised objects, personal pronouns and occasionally human proper names, leading to a high degree of similarity with Old Spanish, where only pronouns 
and dislocated elements were obligatorily $a$-marked. In contrast, he shows that Standard Spanish displays a more developed ром system along all the referential hierarchies. With the exception of the animacy and specificity scales, all other criteria favour the use of Dом and, for some speakers, Dом has come to affect even elements found at the lowest ends in every hierarchy. Finally, he shows that Central Asturian represents an intermediary stage between Standard Modern Spanish and Vaqueiru Asturian since, although Dом appears to occur in Central Asturian in exactly the same contexts as in Standard Spanish, it is possible to observe a greater variation regarding the factors of animacy, definiteness, and specificity. These findings allow us to observe traces of the evolutionary development that this grammatical domain has undergone in the history of Spanish. Its DOM system could have behaved in a manner similar to Vaqueiru Asturian at an earlier stage, thereby linking its origin to discourse properties.

Swintha Danielsen and Tom Durand's article is a comparison of nine Arawakan languages sharing a rare phenomenon in the Americas: differential subject marking. This is the first attempt to establish a typology of this phenomenon in Arawakan languages, which is only mentioned in passing in other studies. The authors understand differential subject marking as the phenomenon involving the use of oblique case markers with the subjects of a group of predicates, similar to the subject-like obliques in Icelandic and Hindi. However, in their study, differential subject marking occurs in languages characterized by split intransitivity. This additional degree of complexity represents a pioneering contribution in typology. Durand and Danielsen show that the two marking strategies, oblique marking and object marking, are in fact complementary. The existence of these two types of marking allows to express semantico-pragmatic subtleties, thus illustrating not only a specific realisation of the differential marking of the subject in non-accusative languages but also how split intransitivity can occur between canonical object marking and oblique marking.

In addition to the synchronic typological comparison, Durand and Danielsen's contribution offers diachronic and areal explanations on the origins of this phenomenon. A comparison with bivalent constructions provides a strong argument for the diachronic process whereby objects gradually acquired subject properties. If we consider the areal characteristics, the possibilities of language contact with non-Arawakan languages such as Tukanoan or Witotoan languages or with Arawakan languages, especially in the North-Western region of Amazonia, the absence of other languages with differential subject marking in South America, and the attestations of this phenomenon in Arawakan languages over a period of 500 years ago, we can only conclude that differential 
subject marking is an inherited characteristic in the Arawakan language family.

Petros Karatsareas looks at differential case marking (DCM) in two inner Asia Minor Greek varieties, Cappadocian Greek and Pharasiot Greek, both of which were in intense contact with Turkish over a period of many centuries. His synchronic analysis engages with the question of which referential property determines DCM in the two Greek varieties: definiteness, as previously argued by Dawkins (1916) and Janse (2004), or specificity, as claimed by Spyropoulos and Tiliopoulou (2006). His results corroborate Dawkins's and Janse's analyses and additionally show that the formal implementation of Cappadocian and Pharasiot DCM is improbable from a typological point of view in that the overt marker $-s$ is found with the unmarked subset of DCM elements. This typological improbability is then considered in combination with the genetic link between the two languages to develop the argument that DCM emerged in the two Greek varieties due to contact with Turkish within a single linguistic micro-area in which all three languages were contiguously spoken. In that, the originally non-differential case marking system of the two Greek varieties was adapted into a differential one by replicating the Turkish model by matching the referential property of specificity with that of definiteness and by adopting the use of the nominative for the unmarked set of objects and the use of the accusative for the marked set of objects. Karatsareas then goes on to explain a set of Cappadocian data in which the replicated DCM pattern is not adhered to. He proposes that these violations can be accounted for in terms of a morphological change that destroyed the morphological distinction between nominative and accusative upon which DCM was based.

Itxaso Rodríguez-Ordóñez's study examines the variable use of differential object marking in Basque as a contact-induced development in the model of Basque Spanish leísmo, a variant of Spanish Dom. The study compares the use of Dом in the spontaneous speech of native bilinguals in Spanish and Gernika Basque, a variety with long-standing contact with Spanish, with that of early sequential speakers from Bilbao who speak a recently standardised variety of Basque. As a way to determine possible contact effects, Rodríguez-Ordóñez used Basque-French bilinguals as a control group. Her results show that Basque DOM is used more among Gernika Basque speakers than among Standard Basque speakers whereas it is almost non-existent among Basque-French bilinguals. Informed by empirical methods in variationist sociolinguistics, Rodríguez-Ordóñez demonstrates that Basque DOM is differently constrained among the two groups of bilinguals: while Dом is constrained by animacy and person in both groups, Gernika Basque speakers make increased use of DOM when they borrow verbs from Spanish and when objects are phonologically 
realised as null; Standard Basque speakers rarely borrow Spanish verbs and, consequently, use less DOM. Additionally, her results show that the speakers' use of Basque Dом is conditioned by their use of leísmo. In that, the more leísmo speakers use the more likely are Basque-Spanish bilinguals to use Basque Dом. Based on these results, Rodríguez-Ordóñez makes an argument that Basque DOM is not a case of syntactic borrowing but rather a case of replica grammaticalization à la Heine and Kuteva (2006, 2010). More specifically, she argues that Standard Basque speakers replicate Spanish leísmo through PAT-borrowing (pattern-borrowing) whereas Gernika Basque speakers resort to both PAT-borrowing and MAT-borrowing (matter-borrowing).

\section{Acknowledgements}

We are grateful to the former and the current editors of the Journal of Language Contact, Professor Robert Nicolaï and Professor Henning Schreiber, for their support in seeing this special issue through. We are also indebted to the specialist reviewers for their most constructive feedback on the individual contributions. We thank Evangelia Adamou, Alexandra Aikhenvald, Metin Bağrıaçı, Eduardo Blasco Ferrer, Swintha Danielsen, Franck Floricic, Aritz Irurtzun, Michael Jones, Georg Kaiser, Jaklin Kornfilt, Béatrice Lamiroy, Manuel Leonetti, Jouko Lindstedt, Io Manolessou, Lev Michael, Marianne Mithun, Juan Romero, Françoise Rose, Andrey Sobolev and Sophie Vassilaki for their work.

\section{References}

Aissen, Judith. 2003. Differential object marking: iconicity vs. economy. Natural Language and Linguistic Theory 21(3): 435-483.

Avram, Mioara. 1997. Gramatica pentru toți. Ediția a II-a. București: Humanitas.

Benincà, Paola. 1988. Lordine degli elementi della frase e le costruzioni marcate. In Lorenzo Renzi (ed.), Grande grammatica italiana di consultazione, 115-195. Bologna: Il Mulino.

Berretta, Monica. 1989. Sulla presenza dell'accusativo preposizionale in italiano settentrionale: note tipologiche. Vox Romanica 13(1): 13-37.

Blasco Ferrer, Eduardo and Giorgia Ingrassia. 2010. Sardo e lingue romanze a confronto: nuove prospettive per la genesi dell'accusativo preposizionale. In Maria Iliescu, Heidi Siller-Runggaldier and Paul Danler (eds.), Actes du $x x v^{\mathrm{e}}$ Congrès International de Linguistique et de Philologie Romanes, 145-158, Berlin/New York: De Gruyter. 
Bossong, Georg. 1985. Empirische Universalienforschung: Differentielle Objektmarkierung in den neuiranischen Sprachen. Tübingen: Gunter Narr.

Bossong, Georg. 1998. Le marquage différentiel de l'objet dans les langues d'Europe. In Jack Feuillet (ed.), Actance et valence dans les langues de l'Europe, 193-258. Berlin/ New York: Mouton de Gruyter.

Chiriacescu, Sofiana and Klaus von Heusinger. 2010. Discourse prominence and pemarking in Romanian. International Review of Pragmatics 2(2): 298-332.

Cohal, Alexandru L. 2014. Mutamenti nel romeno di immigrati in Italia. Milan: FrancoAngeli.

Comrie, Bernard. 1979. Definite and animate direct objects: a natural class. Linguistica Silesiana 3: 13-21.

Comrie, Bernard. 1989. Language Universals and Linguistic Typology: Syntax and Morphology. Chicago: The University of Chicago Press.

Cornilescu, Alexandra. 200o. Notes on the interpretation of the Prepositional Accusative in Romanian. Bucharest Working Papers in Linguistics 2(2): 91-106.

Croft, William. 1988. Agreement vs. case marking and direct objects. In Michael Barlow and Charles A. Ferguson (eds.), Agreement in Natural Language: Approaches. Theories. Descriptions, 159-179. Stanford, CA: CSLI Publications.

Dalrymple, Mary and Irina Nikolaeva. 2011. Objects and Information Structure. Cambridge: Cambridge University Press.

Dawkins, Richard M. 1916. Modern Greek in Asia Minor: A Study of the Dialects of Silli, Cappadocia and Phárasa with Grammar, Texts, Translations and Glossary. Cambridge: Cambridge University Press.

de Swart, Peter and Helen de Hoop. 2007. Semantic aspects of differential object marking. In Estela Puig-Waldmüller (ed.), Proceedings of Sinn und Bedeutung ${ }^{11},{ }_{568-581 .}$ Barcelona: Universitat Pompeu Fabra.

Dobrovie-Sorin, Carmen. 1994. The Syntax of Romanian. Comparative Studies in Romance. Berlin/New York: Mouton De Gruyter.

Heine, Bernd and Tania Kuteva. 2006. The Changing Languages of Europe. Oxford: Oxford University Press.

Heine, Bernd and Tania Kuteva. 2010. Contact and Grammaticalization in Raymond Hickey (ed.), The Handbook of Language Contact, 86-105. Oxford: Wiley-Blackwell.

Hill, Virginia and Alexandru Mardale. 2017. On the Interaction between Differential Object Marking and Clitic Doubling in Romanian. Revue Roumaine de Linguistique 62(4): 393-411.

Hill, Virginia and Alexandru Mardale. 2019. Patterns for differential object marking in the history of Romanian. Journal of Historical Syntax 3.5: 1-47.

Hopper, Paul J. and Sandra A. Thompson. 1980. Transitivity in grammar and discourse. Language $5^{6}$ (2): 251-299. 
Iemmolo, Giorgio. 2010. Topicality and differential object marking: evidence from Romance and beyond. Studies in Language 34(2): 239-272.

Iemmolo, Giorgio. 2011. Towards a Typological Study of Differential Object Marking and Differential Object Indexing. PhD dissertation, Università degli studi di Pavia.

Iemmolo, Giorgio. 2013. Symmetric and asymmetric alternations in direct object encoding. STUF - Language Typology and Universals 66(4): 378-403.

Janse, Mark. 2004. Animacy, definiteness, and case in Cappadocian and other Asia Minor Greek dialects. Journal of Greek Linguistics 5: 3-26.

Laca, Brenda. 2002. Gramaticalización y variabilidad: propriedades inherentes y factores contextuales en la evolución del acusativo preposicional en español. In Andreas Wesch (ed.), Sprachgeschichte als Varietätengeschichte: Beiträge zur diachronen Varietätenlinguistik des Spanischen und anderer romanischer Sprachen; anlässlich des $6 o$ Geburtstages von Jens Lüdtke, 195-303. Tübingen: Stauffenburg.

Laca, Brenda. 2006. El objeto directo: la marcación preposicional. In Concepción Company Company (ed.), Sintaxis histórica de la lengua española. Primera parte: la frase verbal, 423-475. Mexico: Universidad Nacional Autónoma de México/Fondo de Cultura Económica.

Lazard, Gilbert. 1994. L'actance. Paris: Presses Universitaires de France.

Lazard, Gilbert. 2001. Le marquage différentiel de l'objet. In Martin Haspelmath, Ekkehard König, Wulf Oesterreicher and Wolfgang Raible (eds.), Language Typology and Language Universals: An International Handbook, 873-855. Berlin/New York: Walter de Gruyter.

Leonetti, Manuel. 2004. Specificity and differential object marking in Spanish. Catalan Journal of Linguistics 3: 75-114.

Leonetti, Manuel. 2008. Specificity in clitic doubling and in differential object marking. Probus 20(1): 33-66.

Mardale, Alexandru. 2009. Les prépositions fonctionnelles du roumain: études comparatives sur le marquage casuel. Paris: L'Harmattan.

Matras, Yaron and Jeanette Sakel. 2007. Investigating the mechanisms of pattern replication in language convergence. Studies in Language 31(4): 829-865.

Matras, Yaron. 2009. Language Contact. Cambridge: Cambridge University Press.

Næss, Åshild. 2004. What markedness marks: the markedness problem with direct objects. Lingua 114(9-10): 1186-1212.

Nedelcu, Isabela. 2012. 101 greșeli gramaticale. București: Humanitas.

Pană Dindelegan, Gabriela. 2013. The Grammar of Romanian. Oxford: Oxford University Press.

Putzu, Ignazio. 2005. L'accusativo preposizionale in sardo campidanese. In Antonietta Dettori (ed.), Quaderni del Dipartimento di Linguistica e Stilistica dell'Università di Cagliari: Lingue e culture in contatto, 225-260. Roma: Carocci. 
Riaño Rufilanchas, Daniel. 2014. Differential object marking in Ancient Greek. Linguistics 52(2): 513-541.

Sakel, Jeanette. 2007. Types of loan: matter and pattern. In Yaron Matras and Jeanette Sakel (eds.), Grammatical Borrowing in Cross-Linguistic Perspective, 15-29. Berlin/ New York: Mouton de Gruyter.

Seržant, Ilja A. and Alena Witzlack-Makarevich. 2018. The Diachronic Typology of Differential Argument Marking. Language Science Press.

Spyropoulos, Vassilios and Maria-Anna Tiliopoulou. 2006. Definiteness and case in Cappadocian Greek. In Mark Janse, Brian Joseph, and Angela Ralli (eds.), Proceedings of the 2nd International Conference on Modern Greek Dialects and Linguistic Theory, Mytilene, Greece, 30 September - 3 October 2004, 365-378. Patras: University of Patras.

von Heusinger, Klaus and Georg A. Kaiser. 2007. Differential object marking and the lexical semantics of verbs in Spanish. In Georg A. Kaiser and Manuel Leonetti (eds.), Proceedings of the Workshop "Definiteness, Specificity and Animacy in Ibero-Romance Languages”, Arbeitspapier 122, 85-110. Konstanz: Universität Konstanz. 